\title{
Some Properties of a Glass Used in Paper Manufacture
}

\author{
Martin J. O'Leary and Donald Hubbard
}

\begin{abstract}
The chemical durability, heterogeneous equilibria, hygroscopicity, $p \mathrm{H}$ response, dispersal, and thermal expansion characteristics of a fiber glass used in paper manufacture were investigated. The chemical durability of this glass was found to be very poor between $p H$ 2 and $p \mathrm{H}-2$, apparently due to the high alumina and low silica composition. Above and below this range the chemical durability greatly improved, showing with the interferometer no detectable attack for exposures of 6 hours at $80^{\circ} \mathrm{C}$ either in high concentrations of $\mathrm{H}_{2} \mathrm{SO}_{4}$, or between $p \mathrm{H} 4$ and $p \mathrm{H} 8$. At alkalinities above $p \mathrm{H} 8$ the durability again decreased as is characteristic of many silicate glasses. In addition, the heterogeneous equilibria at the solution-glass interface, using $\mathrm{Ag}\left(\mathrm{NH}_{3}\right)_{2}+$ ions as indicator, showed the fiber glass when leached at $p \mathrm{H} 4.1$ to have an uneven distribution of migratable ions between the negatively charged glass surface and ambient aqueous solutions, to a greater extent than most commercial glasses. In accord with the very low hygroscopicity and poor chemical durability, electrodes prepared from this glass gave no definite response to hydrogen ion activity of the ambient solutions. The dispersal characteristics of the fibers in aqueous solutions follow the "critical" points indicated by the chemical durability curve covering the range from $p \mathrm{H}-8.1$ to $p \mathrm{H} 11.8$. The annealing and softening temperatures as obtained from the respective expansion curves were found to be higher for the fiber glass than for either Pyrex 7740 or Kimble N 51-A.

The chemical durability data, the acid titration of sodium silicate, and the dispersal- $p \mathrm{H}$ series are consistent with the findings of O'Leary et al. in emphasizing $p \mathrm{H} 2.9$ as a critical condition for the most successful production of paper from fibers of this glass.
\end{abstract}

\section{Introduction}

During the developmental stages in the production of paper from glass fibers $[1,2]^{1}$ it became evident that optimum conditions of strength and quality of the finished product were obtained upon adjusting the hydrogen ion concentration of the suspended fibers to near $p \mathrm{H} 2.9$ prior to the fabrication of the paper [3]. When the hydrogen ion activity was adjusted toward lower or higher values of $p \dot{H}$, the strength of the finished paper was greatly reduced. Of considerable significance from an industrial standpoint was the observation that the fibers dispersed rapidly at this optimum condition and distributed themselves evenly throughout the liquid medium, insuring uniformity of the resulting sheet. At high $p \mathrm{H}$ values the fibers showed a strong tendency to remain in clumps and required a much longer time to disperse adequately for paper making $[1,3]$.

Some of the improved strength of the paper was attributed to the cementing together of the dried fibers by the swollen gelatinous silica-rich layer [3] that is known to be formed on many types of silicate glasses during leaching in acid buffers [4 to 9]. Further partial rationalization of the cause for this increased strength at or near $p \mathrm{H} 2.9$ was postulated from the titration curve of sodium silicate by $\mathrm{HCl}$ [10], typical voltage departure curves of the glass electrode $[11,12]$, and the repression of swelling of electrode glasses in the "super acid" region below $p \mathrm{H} 2[5,13]$.

In order to obtain a better understanding of the fabrication of paper from glass fibers, the present investigation was undertaken to study the chemical

${ }_{1}$ Figures in brackets indicate the literature references at the end ot this paper. durability, heterogeneous equilibria, hydroscopicity, $p \mathrm{H}$ response, dispersal, and thermal expansion characteristics of a fiber glass (E type, table 1) used in the production of paper; a general comparison was made with a few of the more familiar commercial, experimental, optical, and natural glasses.

TABLE 1. Composition of glasses arranged in the order of decreasing percentage of $\mathrm{SiO}_{2}$

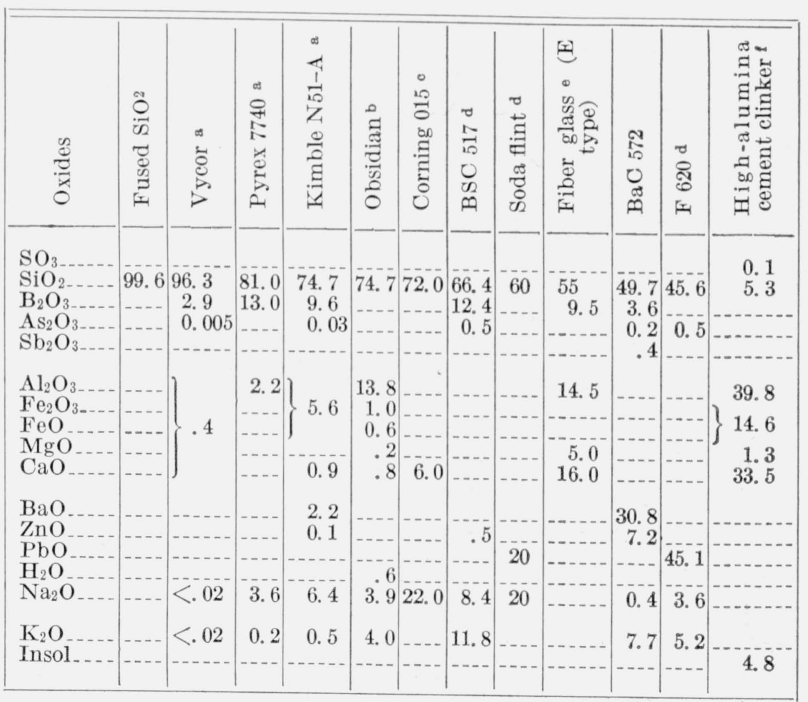

a Analyses by F. W. Glaze, J. Research NBS 26, 538 (1941) RP1394.

h Typical composition of obsidian, George W. Morey [30].

M. Dole [11]

Calculated from bath composition.

- Approximate composition furnished by the manufacturer f Typical composition, R. H. Bogue, The chemistry of portland cement (Rein-
hold Publishing Corp., New York, N. Y., 1947). 


\section{Experimental Procedure}

The determinations of chemical durability were made by the interferometer procedure which indicates in terms of fractions of a wavelength of light the surface alteration of the specimen after exposure to solutions under controlled conditions of time, temperature, and $p \mathrm{H}[9]$. The light source used as a standard of length was the $5876 \mathrm{~A}$ line of the helium spectrum. For the range $p \mathrm{H} 1.8$ to 11.8 the BrittonRobinson universal buffers were used [10, table $57 \mathrm{c}$ ]; for the more acid exposures aqueous solutions of $\mathrm{H}_{2} \mathrm{SO}_{4}$ were employed. All exposures were made at $80^{\circ} \mathrm{C}$ and a durability comparison was made on a $6 \mathrm{hr}$ basis, although some of the exposures were limited to shorter periods. The surface alterations were plotted as positive values in the case of attack and negative values in the case of swelling. The specimens used in these experiments were polished cross sections of the various glasses whose surfaces were ground sufficiently flat to show reasonably straight interference bands when illuminated under a fused silica optical flat. In the case of the fiber glass the interferometer test specimens were prepared from "marbles" of the glass used in fiber manufacture.

In the experiments on heterogeneous equilibria, the uneven distribution of the migratable ions, $\mathrm{Ag}\left(\mathrm{NH}_{3}\right)_{2}{ }^{+}$and $\mathrm{Br}^{-}$, at the solution-glass interface was demonstrated by potentiometric titration of the $\mathrm{Ag}^{+}$and $\mathrm{Br}^{-}$ions. The $\mathrm{Ag}: \mathrm{AgBr}$ and glass electrodes were used as indicator and reference electrode, respectively $[13,14]$.

The hygroscopicity values represent the amounts of water sorbed by powdered samples, (approximately $1.5 \mathrm{~g}$ that passed through a Tyler standard 150 mesh sieve, equivalent to a U. S. Standard Sieve No. 140) upon exposure for 1 and $2 \mathrm{hr}$ to the high relative humidity, approximately 98 percent, maintained by a saturated solution of $\mathrm{CaSO}_{4} \cdot 2 \mathrm{H}_{2} \mathrm{O}$ at room temperature (6).

The expansion measurements were made, using Saunders' modification of the Fizeau interferometric method [15].

Glasses of the composition given in table 1 are those compared in this investigation.

\section{Results and Discussions}

\subsection{Chemical Durability}

In figure 1, plotted from the data given in table 2 , the chemical durability of the fiber glass is compared with the chemical durabilities of a $\mathrm{Na}_{2} \mathrm{O}-\mathrm{PbO}-\mathrm{SiO}_{2}$ glass and with three typical optical glasses- $\mathrm{BaC}$ 572 , BSC 517, and $\mathrm{F} 620$ over a range $p \mathrm{H} 2$ to $p \mathrm{H}$ 11.8 for exposure periods of $6 \mathrm{hr}$ at $80^{\circ} \mathrm{C}$. These four types are examples of glasses having poor chemical durability. Figure 2 and table 3 offer a similar comparison with Corning 015 and three glasses of known chemical durability, Pyrex 7740, fused silica, and a natural glass (obsidian from Yellowstone Park). In these figures the fiber glass

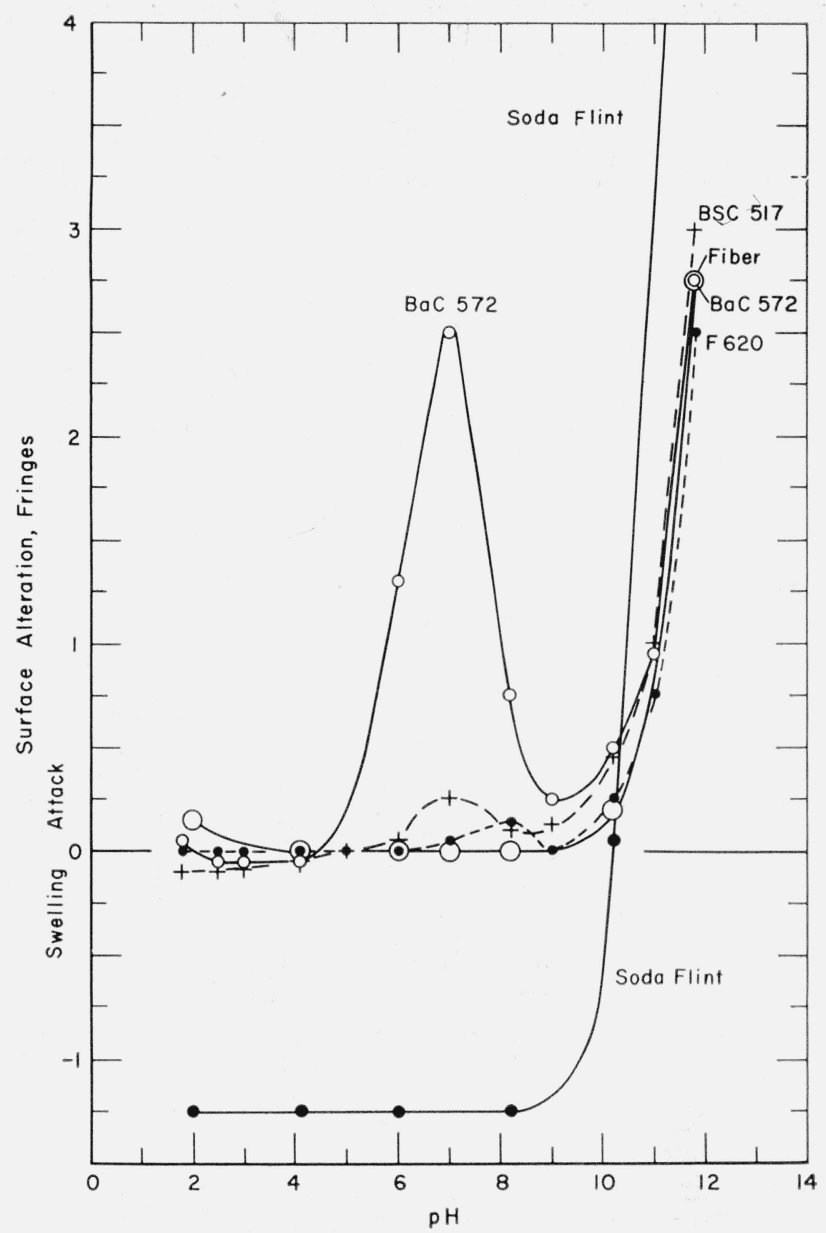

Figure 1. Chemical durability of the fiber glass used in the manufacture of paper compared with three typical optical glasses, BSC 517, $\mathrm{BaC} 572$, and $F$ 620: and with an experimental $\mathrm{Na}_{2} \mathrm{O}-\mathrm{PbO}-\mathrm{SiO}_{2}$ (soda flint) glass.

Data by Bernard R. Nebel, M. D.

exhibits poor durability in the acid range below $p \mathrm{H} 4$. However, it shows none of the conspicuous breakdown of chemical durability between $p \mathrm{H} 5$ and $p \mathrm{H} 9$, characteristic of the optical glasses, particularly $\mathrm{BaC} 572$. In the alkaline range the chemical durability of the fiber glass is inferior beyond approximately $p \mathrm{H} 8$, as is characteristic of many silicate glasses.

The decrease in the chemical durability indicated for the fiber glass below $p \mathrm{H} 4.1$ made it desirable to obtain information at still lower $p \mathrm{H}$ values. The data in table 4 and figure 3 extend the curve for chemical durability in the acid range to $p \mathrm{H}-8.1$ by using aqueous solutions of $\mathrm{H}_{2} \mathrm{SO}_{4}$. Although it is obvious that such values as $p H-8.1$ cannot be interpreted in the Arrhenius sense [16], i. e., cannot represent concentration of hydrogen ions in moles per liter, nevertheless, the $p \mathrm{H}$ values calculated from measurements by the hydrogen-saturated $\mathrm{KCl}-$ calomel cell are plotted in order to extend the curve for convenience in representing the data. 


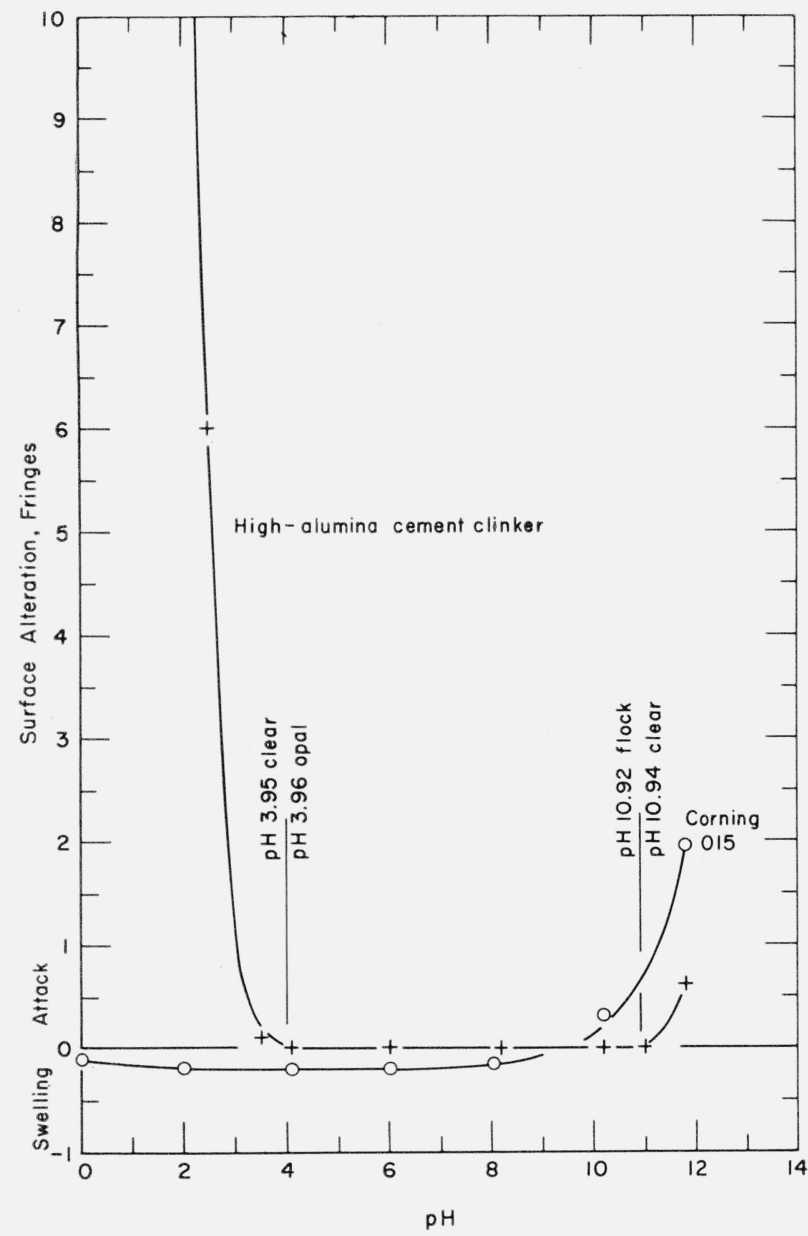

Figure 4. Comparison of the chemical durabilities over an extended $p \mathrm{H}$ range of high-alumina glass-bearing cement Clinker and Corning 015 .

Exposure 6 hours at $80^{\circ} \mathrm{C}$. The vertical lines at $p \mathrm{H} 3.96$ and $p \mathrm{H} 10.94$ inclose the range over which precipitation of $\mathrm{Al}(\mathrm{OH})_{3}$ takes place.

The specimens showed very vigorous attack between $p \mathrm{H} 2$ and $p \mathrm{H}-2$, with marked improvement in chemical durability both above and below this region. In order to appreciate the significance of the resulting curve it is desirable to observe the appearance of the specimens (surface colorations) after exposure at each $p \mathrm{H}$ (table 4 and fig. 3). From $p \mathrm{H} 11.8$ to $p \mathrm{H} 4$, and from $p \mathrm{H}-2.4$ to $p \mathrm{H}-8.1$ the surfaces are clear. The specimens exposed within the range from $p \mathrm{H} 3$ to $p \mathrm{H}-1.5$ show interference colors (reflection-reducing films) on the surface, even for those specimens at $p \mathrm{H} 0.75$ and $p \mathrm{H} 0$ that were etched and pitted. Such colors are normally the result of preferential leaching of cations from the glass, thus leaving behind a swollen silica-rich layer similar to that exhibited by Corning 015 glass, and by the optical glasses under certain conditions (table 2).

The $p \mathrm{H}$ at which color first becomes evident for the fiber glass coincides with the optimum $p \mathrm{H} 2.9$ for the production of paper from this glass. The fact that the interferometer disclosed attack instead of swelling for the fiber glass is the result of the partial sloughing off of the relatively weak silica-rich layer produced initially [13]. The high $\mathrm{Al}_{2} \mathrm{O}_{3}$, high alkaline earth, low $\mathrm{SiO}_{2}$ composition of the fiber glass (table 1) is the main contributing factor in this breakdown. This breakdown does not take place in the presence of equal amounts of $\mathrm{Al}_{2} \mathrm{O}_{3}$ and high percentages of $\mathrm{SiO}_{2}$, as exemplified by the behavior of obsidian (fig. 2). That the effect is not centered around the $\mathrm{CaO}$ has been demonstrated in published work on $\mathrm{Na}_{2} \mathrm{O}-\mathrm{CaO}-\mathrm{SiO}_{2}$ glasses [6]. This point is further emphasized in table 5 and figure 4 in which is shown the weakening of chemical durability contributed by the presence of relatively large percentages of $\mathrm{Al}_{2} \mathrm{O}_{3}$ in a glassy, high-alumina cement clinker. The data indicating the $p \mathrm{H}$ values at which the transition takes place for the solution and precipitation of aluminum hydroxide are represented in figures 3 and 4 by vertical lines [17]. It is also surprising how close this $p \mathrm{H} 3.96$ coincides with the $p \mathrm{H}$ at which the glass fiber begins to show clumping in the paper manufacturing process. Another interesting feature of figure 3 includes one observation of swelling at $p \mathrm{H} 10.2$ shown as a broken line. Very likely similar observations of swelling could be found between $p \mathrm{H} 3$ and $p \mathrm{H}-2$ provided sufficiently short exposures had been given [13].

TABLE 5. Chemical durability of high-alumina cement clinker compared with a soft glass tubing (Corning 015)

\begin{tabular}{|c|c|c|c|c|c|c|c|c|c|c|}
\hline \multirow{2}{*}{ Specimen } & \multicolumn{10}{|c|}{ Surface alteration, $6 \mathrm{hr}$ exposure at $80^{\circ} \mathrm{C}$ and $p \mathrm{H}$ of -} \\
\hline & 0 & 2 & 2.5 & 3.5 & 4.1 & 6.0 & 8.2 & 10.2 & 11 & 11.8 \\
\hline High-alumina cement clinker --. & $\begin{array}{c}\text { Fringes } \\
\text { Disintegrated ... }\end{array}$ & $\begin{array}{l}\text { Fringes } \\
24 \mathrm{~A}^{\mathrm{s}} \ldots\end{array}$ & $\begin{array}{l}\text { Fringes } \\
6 \mathrm{~A}\end{array}$ & $\begin{array}{l}\text { Fringes } \\
0.1 \mathrm{~A}\end{array}$ & $\begin{array}{l}\text { Fringes } \\
\text { D? }\end{array}$ & $\begin{array}{l}\text { Fringes } \\
\text { ND }\end{array}$ & $\begin{array}{l}\text { Fringes } \\
\text { ND }\end{array}$ & $\begin{array}{l}\text { Fringes } \\
\text { ND }\end{array}$ & $\begin{array}{l}\text { Fringes } \\
\text { D? }\end{array}$ & $\begin{array}{l}\text { Fringes } \\
1 / 2+\mathrm{A} .\end{array}$ \\
\hline Corning $015_{-}$ & $1 / 10 \mathrm{~S}_{\ldots} \ldots$ & $2 / 10-\mathrm{S}_{-}$ & & & $2 / 10-\mathrm{S}$ & $2 / 10-\mathrm{S} \ldots$ & $\mathrm{SC}_{-} \ldots$ & $1 / 4+\mathrm{A} \ldots$ & & $2-\mathrm{A}$. \\
\hline
\end{tabular}

- Symbols explained in table 2 . 
TABLE 2. Chemical durability of fiber glass used in the manufacture of glass paper compared with three typical optical glasses and an experimental $\mathrm{Na}_{2} \mathrm{O}-\mathrm{PbO}-\mathrm{SiO}_{2}$ glass

\begin{tabular}{|c|c|c|c|c|c|c|c|c|c|c|c|c|c|}
\hline \multirow{2}{*}{ Glass } & \multicolumn{13}{|c|}{ Surface alteration in $6 \mathrm{hr}$ exposure at $80^{\circ} \mathrm{C}$ and $p \mathrm{H}$ of -} \\
\hline & 1.8 & 2.0 & 2.5 & 3.0 & 4.1 & 5.0 & 6.0 & 7.0 & 8.2 & 9.0 & 10.2 & 11 & 11.8 \\
\hline Fiber glass. - & Fringes & $\begin{array}{l}\text { Fringes } \\
2 / 10 \mathrm{~A} \text { a } \\
\text { (purple) }\end{array}$ & Fringes & Fringes & $\begin{array}{l}\text { Fringes } \\
\text { ND h } \\
\text { (clear) }\end{array}$ & Fringes & $\begin{array}{l}\text { Fringes } \\
\text { ND } \\
\text { (clear) }\end{array}$ & $\begin{array}{l}\text { Fringes } \\
\text { ND } \\
\text { (clear) }\end{array}$ & $\begin{array}{l}\text { Fringes } \\
\text { ND } \\
\text { (clear) }\end{array}$ & Fringes & $\begin{array}{l}\text { Fringes } \\
1 / 4-\mathrm{Ag} \\
\text { (clear) }\end{array}$ & Fringes & $\begin{array}{l}\text { Fringes } \\
23 / 4 \mathrm{~A} \\
\text { (clear) }\end{array}$ \\
\hline $\mathrm{BaC} 572^{*} \ldots$ & $\begin{array}{l}\mathrm{D}^{\mathrm{c} A} \mathrm{~A} \\
\text { (purple) }\end{array}$ & - & $\begin{array}{l}\text { DSd } \\
\text { (darker } \\
\text { purple) }\end{array}$ & $\begin{array}{l}\text { DS } \\
\text { (purple) }\end{array}$ & $\begin{array}{l}\text { DS } \\
\text { (green- } \\
\text { ish) }\end{array}$ & . & $\begin{array}{l}11 / 4+\mathrm{A} \\
\text { (dark } \\
\text { haze) }\end{array}$ & $\begin{array}{l}21 / 2 \mathrm{~A} \\
\text { (slight } \\
\text { reticu- }\end{array}$ & $\begin{array}{l}3 / 4 \mathrm{~A} \\
\text { (pitted, } \\
\text { greenish) }\end{array}$ & $\begin{array}{l}\text { 1/4A } \\
\text { (clear) }\end{array}$ & $\begin{array}{l}\text { 1/2A } \\
\text { (clear) }\end{array}$ & $1-\mathrm{A}$ & $\begin{array}{l}2^{3 / 4} \mathrm{~A} \\
\text { (clear) }\end{array}$ \\
\hline BSC $517^{*} \ldots$ & $\begin{array}{l}1 / 10 \mathrm{~S} \\
\text { (purple) }\end{array}$ & - & $\begin{array}{l}\text { 1/10S } \\
\text { (greenish) }\end{array}$ & $\begin{array}{l}\text { DS } \\
\text { (blue) }\end{array}$ & $\begin{array}{l}\text { DS } \\
\text { (bluish) }\end{array}$ & $\begin{array}{l}\text { D? e } \\
\text { (slight) }\end{array}$ & $\mathrm{DA}$ & $\begin{array}{l}\text { lation) } \\
1 / 4 \mathrm{~A}\end{array}$ & $\begin{array}{l}1 / 10 \mathrm{~A}, \\
210 \mathrm{SC}^{f}\end{array}$ & $\begin{array}{l}1 / 10+A \\
\text { (clear) }\end{array}$ & $\begin{array}{l}1 / 2-\mathrm{A} \\
\text { (clear) }\end{array}$ & $\begin{array}{l}1 \mathrm{~A} \\
\text { (clear) }\end{array}$ & $\begin{array}{l}3 \mathrm{~A} \\
\text { (clear) }\end{array}$ \\
\hline MF $620^{*} \ldots$ & $\begin{array}{l}\text { ND } \\
\text { (clear) }\end{array}$ & - & $\begin{array}{l}\text { ND } \\
\text { (clear) }\end{array}$ & $\begin{array}{l}\text { ND } \\
\text { (clear) }\end{array}$ & $\begin{array}{l}\text { ND } \\
\text { (clear) }\end{array}$ & ? & ? & $\begin{array}{l}\text { DA } \\
\text { (clear) }\end{array}$ & $\begin{array}{l}\text { (clear) } \\
1 / 10+\mathrm{A}, \\
1 / 2 \mathrm{SC} \mathrm{A} \\
\text { (clear) }\end{array}$ & $\begin{array}{l}\text { ?A, } \\
\text { (clear) }\end{array}$ & $\begin{array}{l}\text { 1/4A } \\
\text { (clear) }\end{array}$ & $\begin{array}{l}3 / 4 \mathrm{~A} \\
\text { (clear) }\end{array}$ & $\begin{array}{l}21 / 2 \mathrm{~A} \\
\text { (clear) }\end{array}$ \\
\hline $\begin{array}{l}\mathrm{Na}_{2} \mathrm{O}, 20 \% \\
\mathrm{PbO}, 20 \% \\
\mathrm{SiO}_{2}, 60 \%\end{array}$ & & $11 / 4 \mathrm{~S}$ & (......... & . & $11 / 4 \mathrm{~S}$ & -....... & $11 / 4 \mathrm{~S}$ & ....... & $11 / 4 \mathrm{~S}$ & $\mathrm{DA}$ & $\mathrm{DA}$ & ........ & 7 \\
\hline
\end{tabular}

*Data obtained by Bernard R. Nebel (Guest worker at NBS).

a A, attack.

b ND, not detectable.

c D, detectable, but not measurable

d S, swelling.

TABLE 3. Chemical durability of fiber glass compared with obsidian, fused $\mathrm{SiO}_{2}$, Pyrex, and Corning 015

\begin{tabular}{|c|c|c|c|c|c|c|}
\hline \multirow{2}{*}{ Glass } & \multicolumn{6}{|c|}{ Surface alteration, $6 \mathrm{hr}$ exposure at $80^{\circ} \mathrm{C}$ and $p \mathrm{H}$ of -} \\
\hline & 2 & 4.1 & 6 & 8.2 & 10.2 & 11.8 \\
\hline $\begin{array}{l}\text { Fiber glass } \\
\text { Corning } 015 \\
\text { Pyrex } 7740 \\
\text { Fused } \mathrm{SiO}_{2} \\
\text { Obsidian }\end{array}$ & $\begin{array}{l}\text { Fringes } \\
210 \mathrm{~A}^{\mathrm{a}} \\
210-\mathrm{S} \\
\mathrm{ND} \\
\text { ND } \\
\text { ND }\end{array}$ & $\begin{array}{l}\text { Fringes } \\
\text { ND } \\
210-\mathrm{S} \\
\text { ND } \\
\text { ND } \\
\text { ND }\end{array}$ & $\begin{array}{l}\text { Fringes } \\
\text { ND } \\
210-\mathrm{S} \\
\text { ND } \\
\text { ND } \\
\text { ND }\end{array}$ & $\begin{array}{l}\text { Fringes } \\
\text { ND } \\
\text { SC } \\
\text { DA } \\
\text { ND } \\
\text { ND }\end{array}$ & $\begin{array}{l}\text { Fringes } \\
1 / 4-\mathrm{Ag} \\
1 / 4+\mathrm{A} h \\
1 / 4-\mathrm{A} \\
\mathrm{DA} \\
\mathrm{D} ?\end{array}$ & $\begin{array}{c}\text { Fringes } \\
23 / 4 \mathrm{~A} \\
2-\mathrm{A} \\
13 / 4 \mathrm{~A} \\
1 / 2 \mathrm{~A} \\
1 / 4-\end{array}$ \\
\hline
\end{tabular}

a Symbols explained in table 2 .

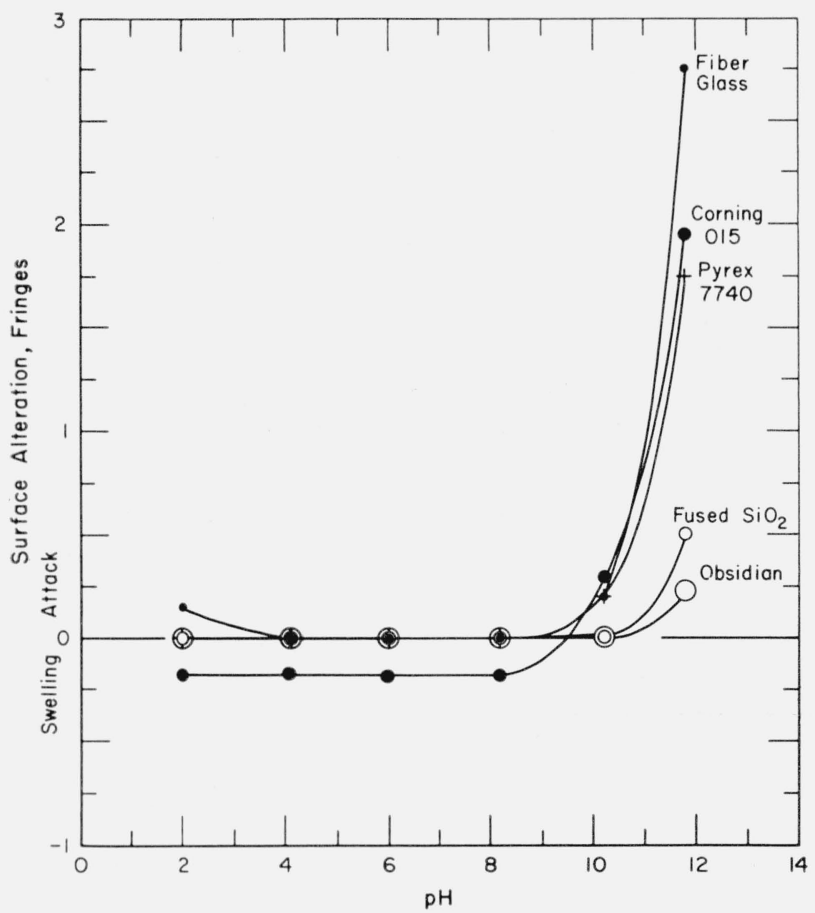

Figure 2. Chemical durability of fiber glass used in the manufacture of paper compared with obsidian (a natural glass from Yellowstone), fused $\mathrm{SiO}_{2}$, Pyrex $\mathrm{\gamma}_{4} 40$, and Corning 015. e ?, indeterminate.

f SC, surface cut at the oil-buffer interface.

g $1 / 4-$, slightly less than $1 / 4$.

h $1 / 4+$, slightly greater than $1 / 4$.

TABLE 4. Chemical-durability characteristics of fiber glass over the range $p H-8.1$ to $p H 11.8$

Exposure $6 \mathrm{hr}$ at $80^{\circ} \mathrm{C}$.

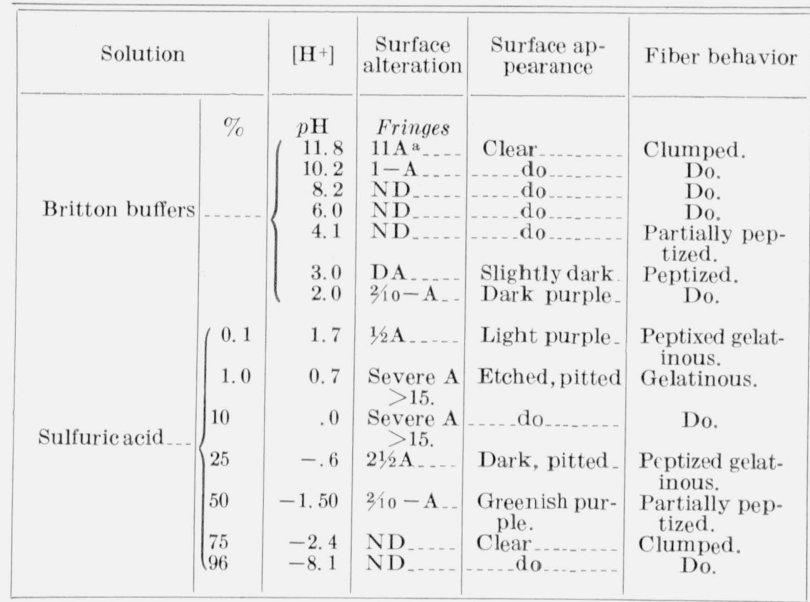

a Symbols explained in table 2.

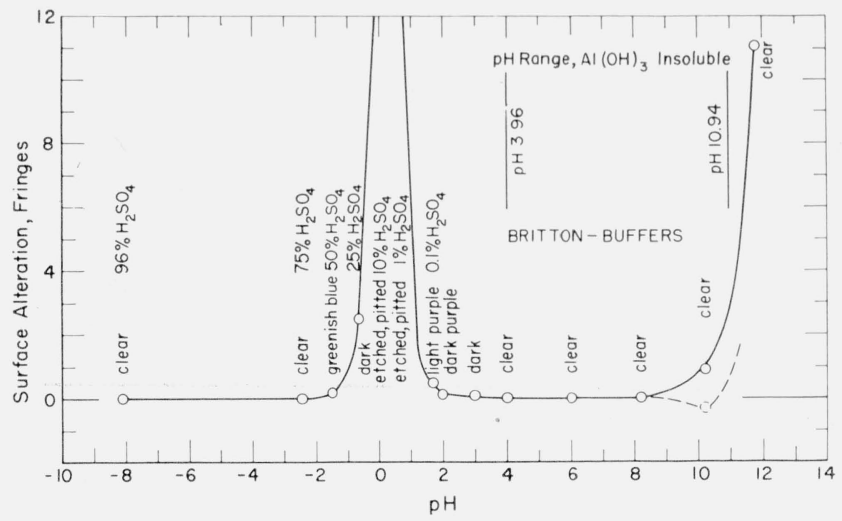

Figure 3. Chemical durability characteristics of fiber glass over the range $p \mathrm{H}=8.1$ to $p \mathrm{H} 11.8$ for exposure of $6 \mathrm{hr}$ at $80^{\circ} \mathrm{C}$.

The vertical lines at $p \mathrm{H} 3.96$ and $p \mathrm{H} 10.94$ enclose the range over which the precipation of $\mathrm{Al}(\mathrm{OH})_{3}$ takes place. 


\subsection{Heterogeneous Equilibria}

Some insight into the nature of the ionic charge on the glass surface and the disintegrating forces operating upon glass can be obtained by studying the heterogeneous equilibria appearing at the solution-glass interface. The uneven distribution of migratable ions at this interface brought about by the presence of the nonmigratable, negatively charged silicate ions left after preferential leaching of cations must necessarily result in an excess of migratable positive ions appearing in the glass surface and of an equal excess of negative ions in the ambient solution. The over-all result at equilibrium is an excess of electrolytes in the glass surface, which give rise to osmotic pressure across the interface, causing the surface to swell as long as it is chemically and mechanically durable [13]. The uneven distribution of migratable ions gives a ready indication of the relative chemical durabilities at $p \mathrm{H} 4.1$ of the glasses, as well as a partial picture of the mechanism of the interfacial voltage potential between the solution and the glass surface. This procedure is especially useful under conditions in which the interferometer method is too insensitive. The value $p \mathrm{H} 4.1$ was chosen because the interferometer does not make a ready differentiation of many silicate glasses at this $p \mathrm{H}$, as can be seen from figures 1 and 2 .

Figure 5 plotted from data in table 6 shows that the fiber glass has a greater uneven distribution of migratable ions than the natural glass, obsidian, or the chemical and industrial glasses, such as Pyrex 7740, fused silica, or Vycor. Corning 015, a special glass whose voltages serve as an indicator of the hydrogen-ion activity of aqueous solutions [11], also

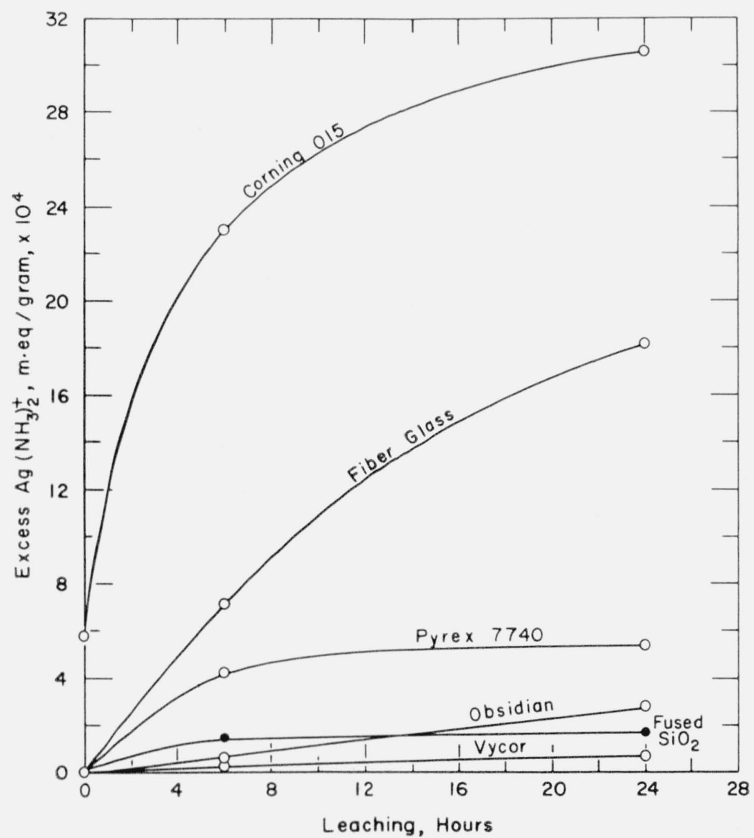

Figure 5. Uneven distribution of migratable ions between the leached surface and the ambient solution using $\mathrm{Ag}\left(\mathrm{NH}_{3}\right)_{2}{ }^{+}$ ion for a comparison of a fiber glass with other special types of industrial glasses and obsidian.

Preleached for various lengths of time, $p \mathrm{H} 4.1$ at $80^{\circ} \mathrm{C}$.
TABLE 6. Uneven distribution of migratable $\mathrm{Ag}\left(\mathrm{NH}_{2}\right)_{2}^{+}$ions, between the glass surface and the ambient solution for a fiber glass compared with obsidian and four special commercial glasses

\begin{tabular}{|c|c|c|c|}
\hline \multirow{2}{*}{ Glass } & \multicolumn{3}{|c|}{$\begin{array}{l}\text { Excess } \mathrm{Ag}\left(\mathrm{NH}_{3}\right)_{2}^{+} \text {ions in surface of } \\
\text { specimens leached at } p \mathrm{H} 4.1,80^{\circ} \mathrm{C} \text { for- }\end{array}$} \\
\hline & $0 \mathrm{hr}$ & $6 \mathrm{hr}$ & $24 \mathrm{hr}$ \\
\hline $\begin{array}{l}\text { Vycor } \\
\text { Fused } \mathrm{SiO}_{2} \\
\text { Obsidian } \\
\text { Pyrex } 7740 \\
\text { Fiber glass } \\
\text { Corning } 015\end{array}$ & $\begin{array}{c}M-e q / g \\
0.1 \times 10^{-4} \\
<.1 \\
<.1 \\
<.2 \\
<.2 \\
5.8\end{array}$ & $\begin{array}{c}M-e q / g \\
0.3 \times 10^{-4} \\
1.4 \\
0.6 \\
4.2 \\
7.1 \\
23.0\end{array}$ & $\begin{array}{c}M-e q / g \\
0.75 \times 10^{-4} \\
1.7 \\
2.8 \\
5.4 \\
18.2 \\
30.6\end{array}$ \\
\hline
\end{tabular}

has a larger uneven distribution of migratable ions than the other glasses.

It is of interest to note the curves for obsidian and fused silica cross, as observed in earlier experiments [14], showing that the rate at which negatively charged silicate ions are made available during leaching changes for these two glasses. Another interesting observation is that under the conditions of the test the sample of Vycor was superior to the specimen of fused $\mathrm{SiO}_{2}$.

\subsection{Hygroscopicity}

Values of hygroscopicity (water sorbed from the vapor state) for the fiber glass compared with other glasses are given in table 7 . Low values of hygroscopicity are indicative of the ability of a glass to maintain a clear polished surface upon exposure to water vapor, a property different from chemical durability. The latter term is generally applied to the capacity of a glass to withstand attack by solutions [18]. The chemical durability of the fiber glass is inferior, although its hygroscopicity compares favorably with that of fused silica and Vycor. This low hygroscopicity is in accord with the high electrical resistance of the surface shown by the fiber glass at high relative humidities [19, p. 407].

TABLE 7. Chemical durability, heterogeneous equilibria, hygroscopicity and $p \mathrm{H}$ response of fiber glass for comparison with a series of $\mathrm{Na}_{2} \mathrm{O}-\mathrm{CaO}-\mathrm{SiO}_{2}$ glasses and a few commercial and natural glasses

\begin{tabular}{|c|c|c|c|c|c|c|c|}
\hline \multicolumn{3}{|c|}{ Glasses } & \multicolumn{2}{|c|}{ Leached $6 \mathrm{hr}, 80^{\circ} \mathrm{C}$ at $p \mathrm{H} 4.1$} & \multicolumn{2}{|c|}{ Water sorbed } & \multirow{2}{*}{$\begin{array}{l}p \mathrm{H} \text { re- } \\
\text { sponse }\end{array}$} \\
\hline $\mathrm{Na}_{2} \mathrm{O}$ & $\mathrm{CaO}$ & $\mathrm{SiO}_{2}$ & $\begin{array}{l}\text { Surface } \\
\text { alteration }\end{array}$ & $\frac{\text { Excess }}{\operatorname{Ag}\left(\mathrm{NH}_{3}\right)_{2}^{+}}$ & $1 \mathrm{hr}$ & $2 \mathrm{hr}$ & \\
\hline $\begin{array}{l}\% \\
10 \\
15 \\
20 \\
25 \\
26 \\
27 \\
28 \\
29.5 \\
30\end{array}$ & $\begin{array}{l}\% \\
20 \\
15 \\
10 \\
5 \\
4 \\
3 \\
2 \\
0.5 \\
0\end{array}$ & $\begin{array}{l}\% \\
70 \\
70 \\
70 \\
70 \\
70 \\
70 \\
70 \\
70 \\
70\end{array}$ & $\begin{array}{c}\text { Fringes } \\
\text { ND } \\
\text { ND } \\
\text { ND } \\
1 / 2+\mathrm{S} \\
2 \mathrm{~S} \\
6 \mathrm{~S} \\
30 \mathrm{~S} \\
75 \mathrm{~S} \\
126 \mathrm{~S}\end{array}$ & $\begin{array}{l}M-e q / g \\
3.1 \times 10^{-4} \\
5.3 \\
7.2 \\
42 \\
63 \\
109 \\
660 \\
480^{\mathrm{b}} \\
<2^{\mathrm{b}}\end{array}$ & $\begin{array}{c}\mathrm{mg} / \mathrm{cm}^{3} \\
14 \\
20 \\
35 \\
70 \\
80 \\
92 \\
108 \\
135 \\
152\end{array}$ & $\begin{array}{c}\mathrm{mg} / \mathrm{cm}^{3} \\
21 \\
36 \\
88 \\
160 \\
185 \\
219 \\
249 \\
314 \\
379\end{array}$ & $\begin{array}{c}m v / p \mathrm{H} \\
0 \\
31 \\
59 \\
59 \\
59- \\
57 \\
55 \\
42 \\
19 \mathrm{~b}\end{array}$ \\
\hline \multicolumn{3}{|c|}{$\begin{array}{l}\text { Fused } \mathrm{SiO}_{2} \\
\text { Vycor } \\
\text { Fiber glass } \\
\text { Obsidian } \\
\text { Australite } \\
\text { Pyrex } \\
\text { Corning }\end{array}$} & $\begin{array}{r}\text { ND } \\
N D \\
N D \\
N D \\
N D \\
N D \\
2 / 10-S\end{array}$ & $\begin{aligned} 1.4 \\
<0.3 \\
7.1 \\
0.6 \\
1.6 \\
4.2 \\
23\end{aligned}$ & $\begin{array}{r}5.6 \\
5.8 \\
5.9 \\
8.9 \\
10.1 \\
18.5 \\
61\end{array}$ & $\begin{array}{l}10.5 \\
11 \\
11.2 \\
13.9 \\
15.3 \\
26 \\
125\end{array}$ & $\begin{array}{r}0 \\
0 \\
0 \\
0 \\
0 \\
12 \\
59\end{array}$ \\
\hline
\end{tabular}

- Symbols explained in table 2 .

b Values indicate that silica rich layers had sloughed off [13]. 


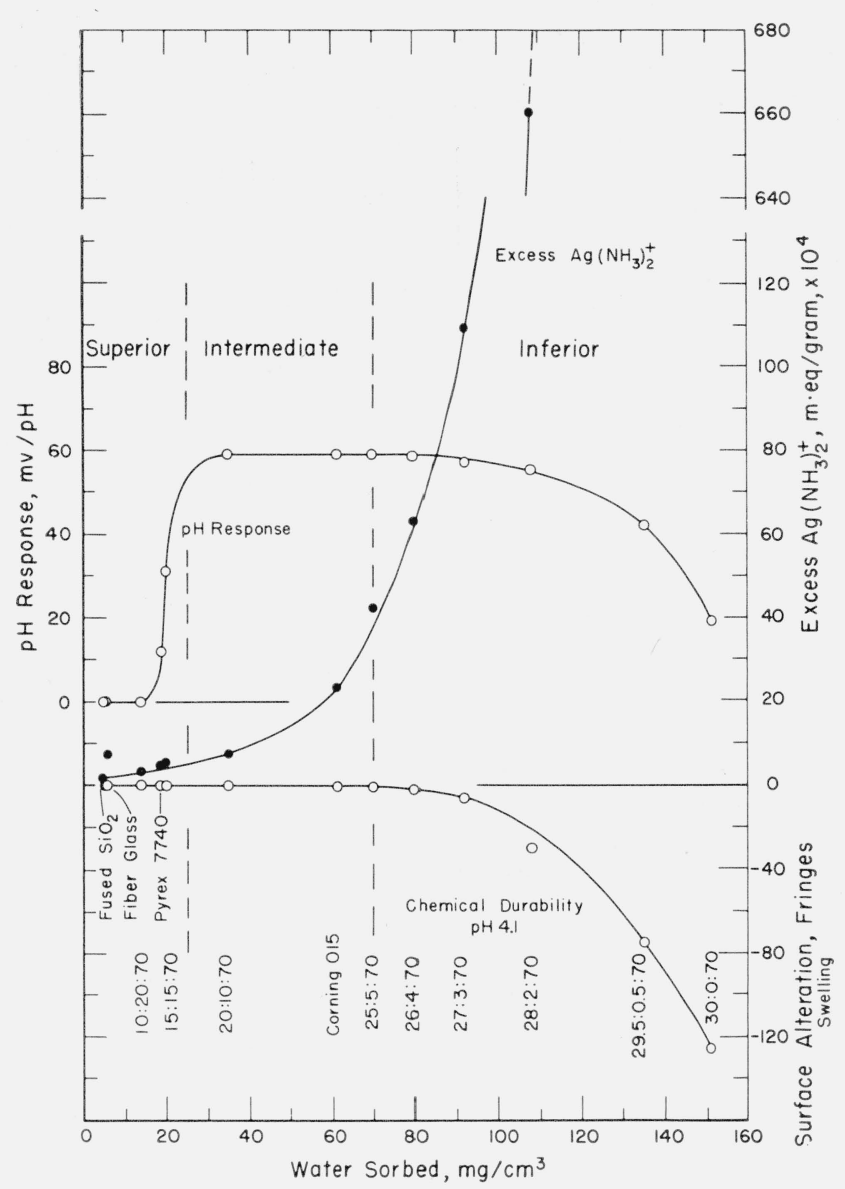

Figure 6. Comparison of the properties; $p \mathrm{H}$ response, heterogeneous equilibria (uneven distribution of $\mathrm{Ag}\left(\mathrm{NH}_{3}\right)_{2}^{+}$and $\mathrm{Br}^{-}$ions at the solution-glass interface), chemical durability at $p \mathrm{H}$ 4.1, and the hygroscopicity of fiber glass, fused $\mathrm{SiO}_{2}$, Pyrex $7 \% 40$, Corning 015, and a series of $\mathrm{Na}_{2} \mathrm{O}$ $\mathrm{CaO}-\mathrm{SiO}_{2}$ glasses containing 70 percent $\mathrm{SiO}_{2}$.

The composition of the reference series is given as weight percent in the ratio $\mathrm{Na}_{2} \mathrm{O}: \mathrm{CaO}: \mathrm{SiO}_{2}$. In general the superior utility glasses fall in the hygroscopicity range labeled "Superior".

\section{4. $p \mathrm{H}$ Response}

Glass electrodes prepared from samples of the fiber glass showed no definite voltage response to hydrogen-ion activity of aqueous buffer solutions (table 7). This is in accord with previous observations that the voltage of electrodes prepared from glasses of low hygroscopicity have always failed to serve as satisfactory indicators of hydrogen-ion activity of aqueous solutions $[6,11]$.

An over-all picture of the position occupied by the fiber glass with respect to other glasses is given in table 7 and figure 6 . In this figure the properties of chemical durability, uneven distribution of $\mathrm{Ag}$ $\left(\mathrm{NH}_{3}\right)_{2}^{+}$ions, and $p \mathrm{H}$ response are plotted as variables dependent upon the hygroscopicity as the abscissa. A series of $\mathrm{Na}_{2} \mathrm{O}-\mathrm{CaO}-\mathrm{SiO}_{2}$ glasses containing 70 percent of $\mathrm{SiO}_{2}$ is included for comparison. For qualitative orientation this series of reference glasses is divided into three utility groups based on commercial experience: superior, intermediate, and inferior. It can be seen that the value obtained for the uneven distribution of $\mathrm{Ag}\left(\mathrm{NH}_{3}\right)_{2}^{+}$ions for the fiber glass does not coincide with the trend indicated by the other glasses. This illustrates the fact that the chemical durability of this glass as determined from heterogeneous equilibria data is not as good as the hygroscopicity might imply.

\subsection{Dispersal Characteristics}

The tendency of the glass fibers to disperse and distribute themselves uniformly throughout the aqueous medium is illustrated in figure 7 . Each member of the series consists of $0.25 \mathrm{~g}$ of fiber immersed in 50 $\mathrm{ml}$ of buffer at room temperature. The series was prepared for direct observation, and comparison with the chemical durability curve for fiber glass shown in figure 3. The solutions range from $p \mathrm{H}-8.1$ to $p \mathrm{H} 11.8$ obtained with $\mathrm{H}_{2} \mathrm{SO}_{4}$ and Britton-Robinson universal buffer mixtures.

It is important to observe the correspondence between the $p \mathrm{H}$ values indicated by the peptization series and some of the critical points shown by the chemical durability curve. Perhaps the most interesting observation is that wherever the glass surface after exposure remained clear, the fibers persisted in clumping. This is observed for solutions more alkaline than $p \mathrm{H} 4.1$ and those more acid than $p \mathrm{H}$ -1.49 . In the acid range where interference colors appear on the surface of the exposed specimen, there is rapid dispersal and swelling of the fibers with the formation of gelatinous masses in the beakers for the region where the attack is the severest. The practical optimum found for the production of paper with this glass comes in the narrow range near $p \mathrm{H} 2.9$ at which the first appearance of color begins and before the region of severe acid attack starts.

Another interesting feature is that in going from $p \mathrm{H} 2.9$ to $p \mathrm{H} 4.1$ or higher and return, the dispersion and clumping feature is reversible as shown by repeated cycles. It was interesting to observe that this $p \mathrm{H}$ series of figure 7 maintained its essential features over a period of several months. The marked improvement in chemical durability of this glass in the $\mathrm{H}_{2} \mathrm{SO}_{4}$ solutions of concentrations greater than 50 percent (fig. 3) has been noted for other glasses, particularly in the repression of swelling of Corning 015 electrode glass in high concentrations of electrolytes [13].

It will be of interest to learn whether fibers produced from more durable silicate glasses show this same critical $p \mathrm{H}$ range for dispersal.

\subsection{Thermal Expansion Characteristics}

Figure 8 shows the expansion. curves for the glass from which the fibers are made compared with the expansion characteristics of Pyrex 7740 and Kimble N 51-A. This figure gives an indication of the upper temperature at which paper made from this fiber glass can be successfully used, i. e., approximately $700^{\circ} \mathrm{C}$ for prolonged periods of time and somewhat higher temperature for shorter cycles. Its deform- 
ing temperature as determined by the interferometer is appreciably higher than either of the other two glasses shown. Inserted in the figure is a portion of the expansion curve for the fiber glass in an unannealed quenched condition. It shows the characteristic dip in the expansion as the temperature approaches the "critical range" $[20$, p. 17] near $630^{\circ} \mathrm{C}$.

Early experiments had shown that the tensile strength of an experimental batch of paper, in. which bentonite had been incorporated with the glass fibers was increased from 386 to 820 psi by heating to $600^{\circ} \mathrm{C}$, and that the density was also appreciably increased [2]. An adverse effect observed was an increase in brittleness of the fibers, a feature characteristic of glass fibers that have been leached and heated. These observations can be partially correlated with the temperatures indicated by the expansion curve, which shows that the temperature of $600^{\circ} \mathrm{C}$ is within the lower limits of the "annealing range" for this glass. The additional strength may have been brought about by initial stages of fluxing the fibers to each other or to the bentonite filler. For other glasses, heating after leaching is known to improve the chemical durability, decrease the hygroscopicity of the surface layer, and greatly lower the voltage response of glass electrodes to hydrogen. ion activity of aqueous solutions [21]. The increase in density of the paper at $600^{\circ} \mathrm{C}$ would be accompanied by normal increase in density that is observed to take place in glasses upon being altered from the "quenched" to the annealed condition. [22].

\section{Relation of Observed Properties to Paper Quality}

The weakness of the fiber glass paper fabricated at values lower than $p \mathrm{H} 2.9$ coincides with a sharp decline in the chemical durability of the glass. The decrease in strength of the paper when formed at $p \mathrm{H}$ values higher than $p \mathrm{H} 2.9$ is associated with a conspicuous tendency for the fibers to clump. This clumping probably interferes with the most advantageous orientation of the fibers for proper matting, and attainment of optimum strength of the finished paper, The evidence furnished by heterogeneous equilibria data and interference colors on the surfaces of the interferometer test specimens, seems to support the assumption that the gelatinous silica-rich layer contributes to the resulting strength of the paper by causing the fibers to adhere at their points of contact when the paper is produced at the optimum acidity near $p \mathrm{H} \mathrm{2.9}$. This feature, however, could be studied to advantage with other glasses of different compositions. As to the ultimate tensile strength that might be attained for papers from glass fibers, it must be borne in mind that such values as 400 psi are but a small fraction of the initial strength of the individual fibers. At the time of their production the tensile strength of glass fibers has often exceeded 2,000,000 psi [19, p. 72].

That the region near $p \mathrm{H} 3$ for maximum strength and quality of the paper from glass fiber is a range of pronounced transition of propertıes for typical silicate glasses can be readily visualized by inspection of figure 9 . In this figure typical tensile strength data for paper from glass fiber are superimposed over the chemical durability curves for three silicate glasses (fiber glass, BaC 572, and Corning 015), typical voltage departure curve for the glass electrode, and a basic silicate-acid titration curve. All of these show a gentle to sharp transition in the approximate region of $p \mathrm{H} 3$. The same $p \mathrm{H}$ region is further emphasized by the peptization- $p \mathrm{H}$ series, (fig. 7) and the position of the appearance of interference colors from reflection reducing films on the surface of the chemical durability test specimens, (fig. 3).

There are other observations from this investigation that are not primarily concerned with the production of paper from glass fibers, but that are of more than passing interest. The data for the three optical glasses given in table 2 and figure 1 when compared with results published years earlier [4] show the need for improvement in the chemical durability of these glasses; their poor durabilities have been contributory to the excessive deterioration of optical instruments and spectacle lenses under conditions of high atmospheric temperature and relative humidity [23]. Of equal interest is the possibility that peptization of glass fibers and paper strength as a function of $p \mathrm{H}$ may constitute useful tools in the study of the so-called "isoelectric point" reported for silicate solutions near $p \mathrm{H} 2.9[24,25]$.

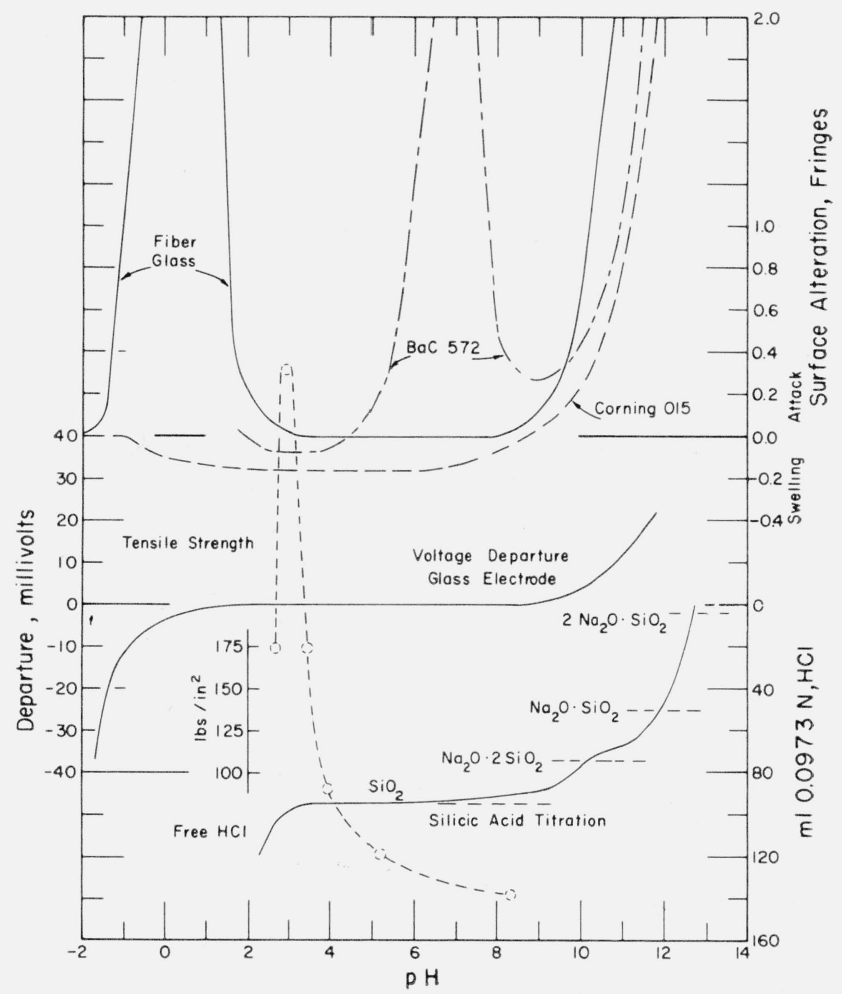

Figure 9. Typical tensile strength $-p \mathrm{H}$ data for paper from glass fiber superimposed on the chemical durability curves of three silicate glasses (fiber glass, $\mathrm{BaC} 572$ and Corning $015)$, characteristic voltage departure curve of the glass electrode, and silicic acid titration curve. 


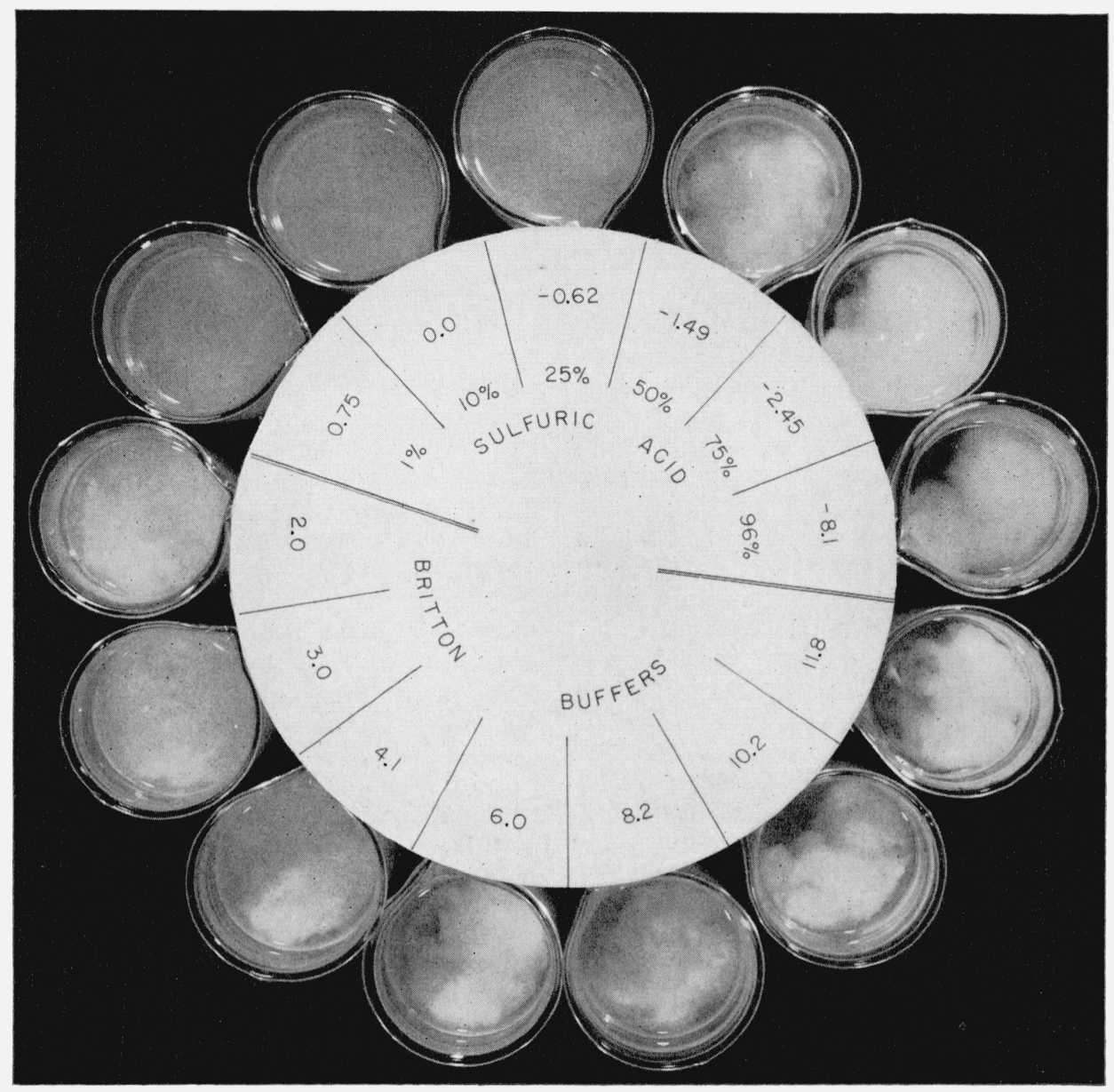

FiguRE 7. Dispersion tendency shown by glass fibers over a range $p \mathrm{H} 11.8$ to $p \mathrm{H}-8.1$, obtained with Britton-Robinson universal buffers and $\mathrm{H}_{2} \mathrm{SO}_{4}$, for comparison with the chemical durability curve for the fiber glass shown in figure 3.

Figure 8. Expansion characteristics of the fiber glass in annealed and "Unannealed quenched" conditions compared with the annealed curves of Pyrex $7_{4} 40$ and Kimble N $51-A$

Data by Herman F. Shermer.

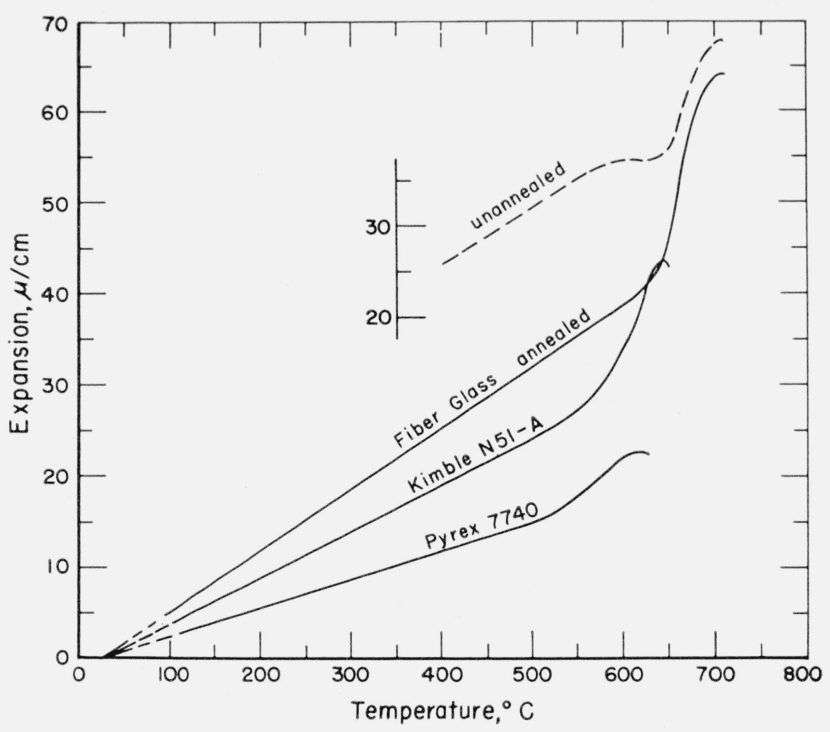




\section{References}

[1] Martin J. O'Leary, Bourdon W. Scribner, Joshua K. Missimer, and James J. Erving, Manufacture of paper from glass fibers, Tappi 35, 289 (1952).

[2] Thomas D. Callinan and Robert T. Lucas, The electrical properties of glass fiber, paper-II, Naval Research Laboratory Report 4042, (Oct. 30, 1952).

[3] Martin J. O'Leary, Robert B. Hobbs, J. K. Missimer, and J. J. Erving, Effect of mechanical preparation and $p \mathrm{H}$ on the strength of glass-fiber paper, Tappi $\mathbf{3 z}, 446$ (1954).

[4] Donald Hubbard and Edgar H. Hamilton, Studies of the chemical durability of glass by an interferometer method, J. Research NBS 27, 143 (1941) RP1409.

[5] Donald Hubbard, Edgar H. Hamilton, and Alfred N. Finn, Effect of the solubility of glass on the behavior of the glass electrode, J. Research NBS 22, 339 (1939) RP1187.

[6] Donald Hubbard, Given W. Cleek, and Gerold F. Rynders, Electrode function ( $p \mathrm{H}$ response), hygroscopicity and chemical durability of $\mathrm{Na}_{2} \mathrm{O}-\mathrm{CaO}-\mathrm{SiO}_{2}$ glasses, $\mathrm{J}$. Research NBS 44, 247 (1950) RP2076.

[7] Donald Hubbard, Mason H. Black, and Gerald F. Rynders, Electrode function ( $\mathrm{H}$ response), hygroscopicity, and chemical durability of soda-lead oxidesilica glasses, J. Research NBS 45, 430 (1950) RP2154.

[8] Donald Hubbard, Mason H. Black, Svlvanus F. Holley, and Gerald F. Rynders, Electrode function $(p \mathrm{H}$ response), hygroscopicity, and chemical durability of soda-potash-silica glasses, J. Research NBS 46, 168 (1951) RP2189.

[9] Donald Hubbard and Given W. Cleek, Deuterium and hydrogen electrode characteristics of lithia-silica glasses. J. Research NBS 49, 267 (1952) RP2363.

[10] H. T. S. Britton, Hydrogen ions, (D. Van Nostrand Co., Inc., N. Y., 1932); also J. Chem. Soc. 425 (1927).

[11] Dole, Glass electrode (John Wiley \& Sons, Inc., New York, N. Y.) ; also Theory of the glass electrode, J. Am. Chem. Soc. 53, 4260 (1931).

[12] D. A. MacInnes and D. Belcher, Further studies on the glass electrode, J. Am. Chem. Soc. 53, 3315 (1931).
[13] Donald Hubbard and Richard G. Goldman, Heterogeneous equilibria at the glass electrode-solution interface, J. Research NBS 48, 428 (1952) RP2333.

[14] Robert G. Pike and Donald Hubbard, an interferometer procedure applied to the study of the chemical durability of silicates, enamels, and metals, J. Research NBS 50, 87 (1953) RP2394.

[15] J. B. Saunders, Improved interferometer procedure with application to expansion measurements, J. Research NBS 23, 179 (1939) RP1227

[16] G. N. Lewis and M. Randall, Thermodynamies, table 4, p. 336 (McGraw-Hill Book Co., New York, N. Y., 1923)

[17] Lansing Wells, Reaction of water on calcium aluminate, BS J. Research 1, table 15 (1928) RP34.

[18] Donald Hubbard, Hygroscopicity of optical glasses as an indicator of serviceability, J. Research NBS 36, 365 (1946) RP1706.

[19] C. J. Phillips, Glass the miracle maker (Pitman Publishing Corp., New York, N. Y., 1941).

[20] Fay V. Tooley, Handbook of glass manufacture (Ogden Publishing Co., N. Y., 1953)

[21] Donald Hubbard and Gerald F. Rynders, Effect of annealing and other heat treatments on the $p \mathrm{H}$ response of the glass electrode, J. Research NBS $\mathbf{4 0}$, 105 (1948) RP1859.

[22] George W. Morey, The properties of glass (Reinhold Publishing Corp., New York, N. Y., 1954).

[23] Wesley Gillis Hutchinson, The deterioration of material in the tropics, The Scientific Monthly, p. 165 (September 1946).

[24] Benjamin Carroll and Eli Freeman, The behavior of colloidal silicate solutions as revealed by adsorption indicators, The Journal of Phys. Chem. 58, 335 (1954).

[25] N. E Gordon, Colloidal symposium monograph 2, 119 (Chemical Publishing Co., New York, N. Y., 1925).

Washington, November 4, 1954 